\title{
Basis for an effective climate change adaptation: Case small Mexican agriculture
}

\author{
Pedro Antonio Guido-Aldana*, Adriana María Ramírez-Camperos** \\ *Mexican Institute of Water Technology, Professional and Institutional Development Coordination, Mexico \\ Email: pedroguido@tlaloc.imta.mx \\ ** Consultant on Water and Energy, Mexico \\ Email: ramirezamar@hotmail.com
}

\begin{abstract}
Mexico is considered one of the world's most vulnerable countries to climate change effects. Its geographical location and climatic, orographic and hydrological conditions contribute considerably to this situation. The objective of this paper is to propose a guide for stakeholders in the selection and efficient design of adaptation measures to face climate change, taking into account constraints on resources availability (financial, technological, human, and others), which force the search of criteria to capitalize actions. The paper consists of four sections: Initially, conceptual and legal framework is present, regarding the issue of climate change, its impact on sectors in Mexico, the identification of the necessity and adaptation capacity and the importance of the interrelation between water, energy and food production. Next, principles for effective adaptation are studied. In the third section, it is discussed through a case study, the efficiency of adaptation policies in small agriculture in Mexico. Final section presents some recommendations and conclusions. It is concluded that adaptation projects proposals should be concrete and clearly address the problem, considering a feasibility analysis. Also, that climate change threatens the stability and productivity of the agricultural sector, which forces society to protect it by progressing to climate-smart production systems in order to strengthen food security.
\end{abstract}

Keywords: Climate change, adaptation measures, policies, small agriculture, smart production system,

\section{INTRODUCTION}

Since the early 1970s, with the creation of the Club of Rome, international efforts to avoid changes in the climate begun, focusing on the issue of mitigation, that is the reduction of Greenhouse Gases (GHG) emissions [1]. Undoubtedly, the next stage must deal directly with adaptation, which implies addressing those impacts that can't be avoided. Challenges faced by societies are not only a necessity issue, but also of equity, because their impacts significantly affect those with less capacity to support them.

Mexico is considered one of the world's most vulnerable countries to the effects of climate change [2]. Its geographical location and climatic, orographic and hydrological conditions contribute considerably to this situation. It is estimated that 15 million Mexicans are at risk of suffering directly floods effects and, at the other extreme, desertification could affect up to 40 percent of the national arable land [3]. Recent vulnerability studies indicate that coastal populations are the most vulnerable because sea level rise, melting of permanent glaciers and moors are expected, as they are reservoirs for water production, which supply Cities and agricultural areas, as well as an increase in the frequency and magnitude of hydrometeorological phenomena [4, 3, 5]. Devastating effects of these phenomena have revealed the necessity to propose, select, design and evaluate measures that allow population to adapt to new climatic conditions, varying in time and with specific characteristics in each region and sector [3].

Effects of climate change are complex, so adaptive measures should be effective in dealing with it. On the other hand, countries don't have sufficient resources for mitigation and adaptation actions implementation. This situation motivated to include prioritization criteria for adaptation and mitigation issues in order to capitalize actions [7].

The search for new technological options motivates that current adaptation projects include concepts such as "Climate-Intelligent Agriculture" [8]. It is also a priority to consider factors such as vulnerability, population willingness to change habits, public policies and governance aspects. It is also necessary to have knowledge about impacts chain, for example in the different productive sectors and the so-called cascade effects through which it is possible to understand how an environmental problem can cause a social problem.

This paper aims to be a reference to guide Stakeholders in the selection and efficient adaptation measures design to face climate change, considering 
limitations on resources availability (financial, technological, human and others), which force the search for criteria and/or principles to capitalize actions. The paper consists of four parts: Initially, a conceptual and legal framework regarding the issue of climate change, its impact on sectors and systems in Mexico, the identification of the necessity and capacity for adaptation, is presented. In second section, effective adaptation principles are studied. In the third, it is discussed through a case study, the efficiency of adaptation policies in small agriculture or family agriculture in Mexico. Fourth section presents recommendations and conclusions.

\section{CONCEPTUAL AND LEGAL FRAMEWORK}

\subsection{CONCEPTUAL FRAMEWORK}

Climate change is defined as a stable and durable change in climate patterns distribution over time periods ranging from decades to millions of years. The concept may refer specifically to the change caused by human activity or those caused by Earth and Solar System natural processes. Although the understanding of the climate change concept and its potential impacts is clearer today, the availability of adaptation practical guidelines has not progressed at the same pace [9]. Also, there is insufficient information in the literature to illustrate criteria for adaptation measures proper selection and principles that should be considered in order to reach effectiveness.

Climate adaptation isn't a new topic. Throughout human history, societies have adapted to natural climate variability by altering settlement patterns, agricultural and other facets of their economies and lifestyles, with different success degrees. Human-induced climate change brings a new complex dimension to this old challenge. On the other hand, the close relationship between climate and society is evident, making it crucial to consider public policy issues (planning, social and economic development, and others).

Climate change adaptations are all those measures and adjustments in human or natural systems to changes in climate to moderate damages or to take advantage of its benefits [10]. Historical climatic variations and recent climatic events (storms, droughts, floods, rising temperatures, precipitation patterns changes, others) demonstrate systems sensitivity to the current climate, i.e. there is an adaptation deficit and are a sign that there will be a requirement to take it into account in the context of climate anticipated variations.

Environmental, economic and social damage caused by climate change has a direct impact on the productive sectors (agricultural, water, health, coastal, energy, food production) and human settlements in different geographical areas of the country [11]. Modern economies base their development on three elements: water, energy and food. However, despite the interrelation between them, public policies have been defined in isolation $[12,13]$. This fragmentation affects the development of the three sectors, a situation that has aggravated with climate change and population growth. One aspect that adds to the problem complexity is that the proposed mitigation and/or adaptation policies affect the balance between these sectors, especially when they are deployed in arid areas and in places with high population density. There is a lack of knowledge about how these three elements interact at different scales, spatial and temporal (see figure 1)

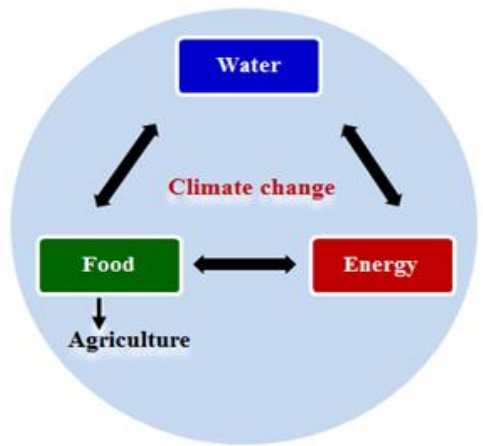

Figure 1. Nexus between water, energy and food. Source: self-made.

Adaptive measures are considered to provide immediate benefits as opposed to mitigation measures, which provide long-term results. Besides it is considered that climate change mitigation has received more attention than adaptation, from scientific as well as normative point of view. The most important reason lies in the ability of mitigation to reduce impacts on all climate-sensitive systems, while adaptation has limited potential for many systems. However, mitigation and adaptation are complementary and do not constitute mutually exclusive alternatives, since their characteristics, temporal, spatial and economic scale, as well as the agents involved are to a large extent different. Figure 2 shows the relationship between mitigation and adaptation actions at present.

Vulnerability refers to conditions under which a system is susceptible to adverse weather effects. Being multifactorial and dynamic, as climate, requires to be monitored [14] and projected [15]. Vulnerability is determined not only by dangerous phenomena occurrence, but also by the way in which societies have developed, are organized and prepared to face them, as well as the way in which they recover from them. Considering that Mexico presents different environmental, economic and social conditions in each State and in each of its Hydrological-administrative regions, 
adaptation must be according to their characteristics, particular necessities and vulnerability level.

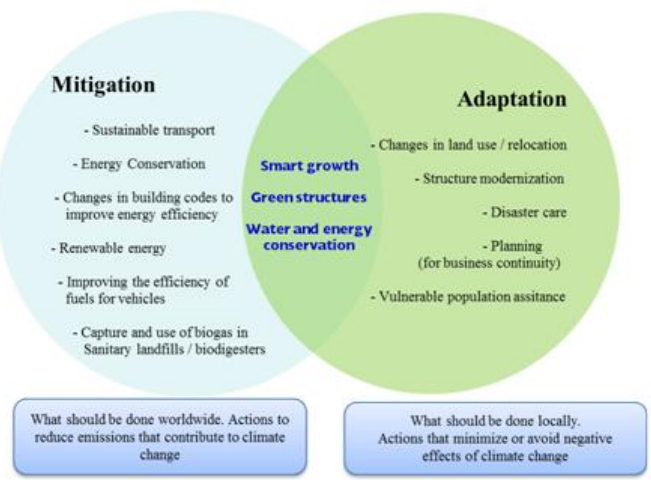

Figure 2. Actions to mitigate and adapt Source: Modified from: http://renewcanada.net/2009/adaptation/

\subsection{LEGAL FRAMEWORK}

Nations global concern due environmental problems, global climate change, day by day is increasing. Mexico is no exception and in recent years has participated in international forums promoted by the United Nations, created laws and instances at Federal level to mitigate environmental impacts. A summary with data for the period 20122016 is presented below $[16,17,18]$.

- 2012. General Law on Climate Change enters into force and the Climate Change Fund is created.

- 2013. Inter-secretarial Commission on Climate Change and the Climate Change Council are created. In addition, the National Climate Change Strategy and Congress approve Carbon Tax for Fossil Fuels.

- 2014. Energy Reform is approved; Special Climate Change Program (2014-2018) is created; National Emissions Inventory and its respective Regulations are approved.

- 2015. Commitments for Mexico 2020-2030 are submitted to the United Nations Framework Convention on Climate Change [19]. Also, the National System of Climate Change is created.

- 2016. Mexico ratifies contributions to AP Climate Change and the Nationally Determined Contribution to Climate Change NDC. Also, Paris Agreement enters into force (Emissions Trading System, ETS). Mexico also participates in global actions for climate, an activity led by the United Nations in Marrakesh COP 22, Morocco, and presents strategies to be followed.

\subsection{IDENTIFICATION OF ADAPTATION NECESSITY AND CAPACITY}

Adaptation necessity arises when the observed impacts or projected risks of climate change require actions that ensure population and its assets safety, including ecosystems and their services. Identifying adaptation necessities, options and building capacity requires appropriate information on risk and vulnerability. [20] points out that negative climate impacts or disaster hazards occur at the place and at the time when events approach or exceed thresholds or tolerance thresholds in different systems. Five categories summarize adaptation necessities: I) Physical and environmental; II) Social; III) Institutional; IV) Necessity to involve private sector and V) Information, training and resources requirements [21]. Generally there is a "tolerance range" for which a community or a system is well adapted to a specific range of different climatic variables (e.g. rain), but is vulnerable to climatic conditions outside this range. For example, low or insufficient rainfall can cause crop damage while excess can cause river overflows and consequently floods.

By means of new investments, it is possible to extend the tolerance range of the system or target population to face events of greater magnitude satisfactorily, but the risk of occurrence of a new one that could exceed extended range is maintained, which imposes a new adaptation challenge. It is clear that uncertainty about the future climate makes it difficult to determine the most appropriate level of adaptation. Several lessons and reflections on the subject are discussed below:

- Adaptation requirements often arise (but not always) from extreme phenomena and not from average climatic conditions.

- Adapting to climate change is a continuous process, not an end state, and requires constant monitoring review of policies, plans and actions.

- Accurate information on future climate change reduces adaptation costs

- Monitoring and evaluation of adaptation results should be carried out, in order to verify the fulfillment of objectives and goals set.

- Planning should be interdisciplinary and multidimensional (differentiating from unidirectional and sectoral planning).

- In Mexico, the early implementation of adaptation measures is crucial, due to high vulnerability and climatic anomalies.

A crucial issue that is not widely discussed in the literature is how to determine adaptive capacity. How can it be possible to know that one has adaptation capacity or what is needed to achieve it? [22] suggest reflecting on the following aspects to find answers:

- Range of technological options available for adaptation.

- Resources availability and its distribution among the population.

- Institutions structure and criteria used in decisionmaking.

- Human capital.

- Access to risk distribution systems, e.g. insurance. 
- The ability of Stakeholders to manage information and determine its credibility.

\section{PRINCIPLES FOR SELECTING AND DESIGNING ADAPTATION MEASURES}

\subsection{EFECTIVE ADAPTATION}

Adaptation should be linked and satisfy specific objectives. It should also be part of public policies given the challenges that society will face in the coming years in terms of water security. Available information, financial resources, skills developed, institutions strengthening, specialized human resources training and technology advances are essential. Determining if the adaptation is appropriate is only possible after its implementation and some time has elapsed. It can happen that the desired or expected result is delayed, not visible or immersed in other changes introduced. Despite these difficulties, experience has shown that taking into account some basic principles it is possible to achieve an effective adaptation [23]. Some principles that should be considered are mentioned below:

- Define and communicate precise objectives and / or results before beginning measure implementation.

- Consider adaptations that allow future actions and from others.

- Work in collaboration with Stakeholders.

- Identify and engage the community, being sure they are well informed.

- Understand risks and know thresholds, including associated uncertainties.

- Identify key climate risks and opportunities to face them, focusing on actions necessary to manage them.

- Recognize the value of adaptation options in which "there is no or little to regret" and those "win-win" in terms of cost-effectiveness and multiple benefits.

\subsection{ADAPTATION OPTIONS}

Numerous adaptation options have been proposed based on the accumulated experience of all effects of climate change; in addition to the necessity to put those effects ahead and increase resilience. However, defined criteria should be available to make a correct selection of measures and thus achieve the greatest benefits. [24] proposes three broad adaptation categories that have been implemented in Latin America and the Caribbean with different success degrees, which are not limiting but demonstrate the wide range of existing possibilities:

I. Structural or physical. Costly and long-term alternatives; should address the uncertainty associated with climate impacts projection.

II. Social. It includes education, information strategies and behavioral measures (diversification of livelihoods, change in farming and livestock practices, crop substitution, soil and water conservation, labor migration, others).

III. Institutional. It considers economy (financial incentives, payments for environmental services, disaster contingency funds), laws and regulations, government policies and programs (disaster planning and preparedness, integrated water resources management, watershed and coastal zone management, Ecosystem-based management and community-based adaptation).

\subsection{IDENTIFICATION OF POTENTIAL OR EXISTING ADAPTATION MEASURES}

The first step in the process of identifying measures is to locate existing and other potential adaptation forms. In the second step, options should be reviewed based on their actual or potential effectiveness to face current vulnerability and climate risk. Third, it is necessary to evaluate the effectiveness of the options identified considering the potential future climate. Finally, priorities should be given. In Figure 3, steps for adaptation measures identification considering recommendations of [25] and [26] are presented.

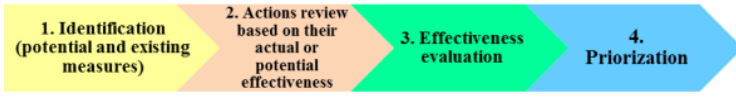

Figure 3. Identification process of adaptation measures.

Source: self-made

Priority selection and prioritization may be possible through various approaches, taking into account their strengths and weaknesses. Most common prioritization techniques are:

- Cost-benefit analysis (CBA).

- Cost-effectiveness analysis (ACE).

- Multicriteria analysis (AMC).

- Expert opinion. DELPHI prospective technique.

Answering the following questions facilitate the identification and/or definition of potential adaptation measures: What would happen if we did nothing about the problem of climate change (lack of public policies in this area)? What are the costs of adaptation? What benefits can be anticipated with the action?

The Adaptation Policy Framework proposed by the United Nations Development Program [27] states that measures should be concentrated on actions that focus on specific issues, whether they could be individual interventions or consist in related sets of measures [28]. Examples of policies targeting a particular issue, such as the national food security target, are: implementation of an irrigation project; an early warning system for farmers; new schemes to ensure crops, others. 


\subsection{MEASURES DESIGN TO ADAPT TO CLIMATE CHANGE}

The design of an adaptation measure or project can be carried out on the basis of schemes proposed by different agencies at global level, such as the United Nations Development Program and the Australian Office for the Greenhouse Effect. The Compendium of the United Nations Framework Convention on Climate Change UNFCCC [29] summarizes different proposals and gathers information on additional frameworks that may be useful in specific situations. Designers should evaluate strengths and weaknesses of each methodology.

The Adaptive Policy Framework of the United Nations Development Program [27, 30] proposes a decision-driven approach, involving affected parties and meeting adaptation necessities.

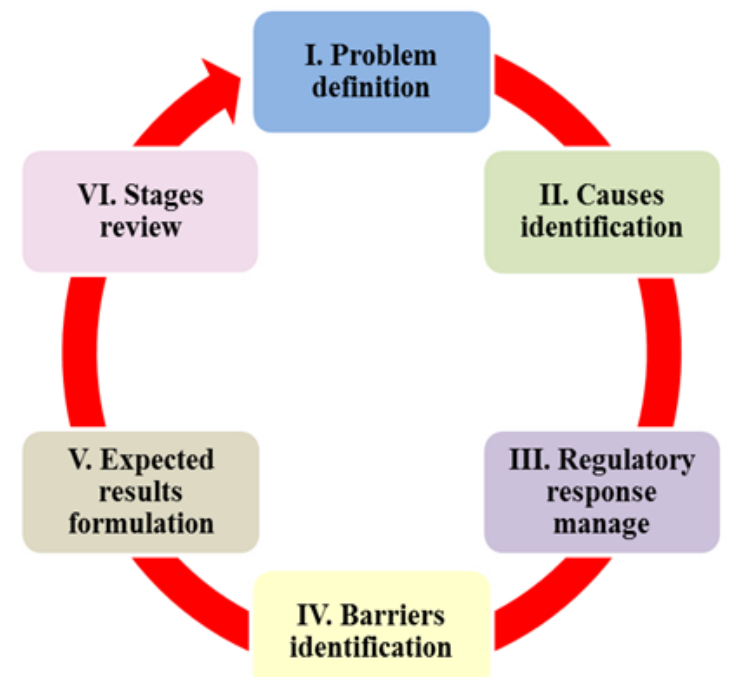

Figure 4. Steps for adaptation measures design. [27]

This type of scheme places greater emphasis on current human concerns, such as vulnerability to climate variability and extreme events. It proposes a sequence of steps to design an adaptation measure which represent a minimum set of activities to be able to define a project with a logical structure. Figure 4 shows the process to be used to design adaptation measures. Key aspects of the different stages are explained below:

I. Problem definition. Problem description caused by climate change should include a diagnosis of current situation, economy, social, environmental and human concerns. [29] proposes the following approaches to analyze it: a. Based on risks b. Based on vulnerability c. Based on adaptive capacity.

II. Identification of problem causes. The United Nations Development Assistance Framework outlines the use of an analytical framework based on the problem tree approach (causality analysis) to help identify key factors that give rise to a problem, see Figure 5.

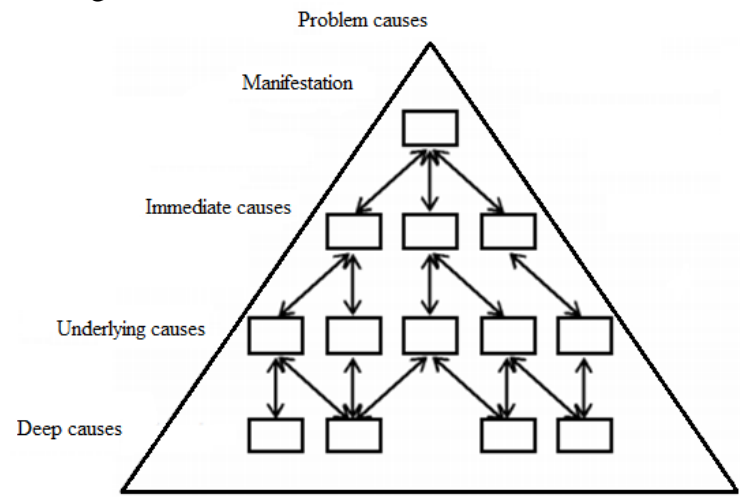

Figure 5. Causality analysis. Problem tree. [27]

In order to fulfill the objective of this step, two particular questions must be answered: What is the cause? Why is it the cause? These questions should be answered iteratively until all the answers are exhausted. Probably a number of non-climate factors that are also at the root of the problem could be found.

III. Identification and management of the normative response. This step consists of identifying and managing the solution that has been considered as the best option to address the root cause of the problem (identified problem and underlying issues). It is based on climate change results and technical assessments (including those resulting from applied research), technical skills (local, regional, national and even international) and political considerations.

IV. Barriers identification. [31] define barriers as conditions or factors that make adaptation difficult to climate change. [32] point out obstacles that can be overcome through concerted effort, creative management, a thought change, setting priorities, and others. Barriers are specific to contexts at local, regional and national levels, and although they are always presented, they can be overcome. [33] explain that barriers and limits to adaptation restrict the ability of individuals and organizations to identify, assess, and manage risks in a way that maximizes well-being. It classifies them as: a. Natural b. Technological c. Policies (institutional and regulatory) d. Market e. Economics f. Social or institutional. In practice, some barriers examples are: - Weak governance, staff lack with relevant knowledge and specific functions.

- Lack of political will.

- Lack of development of required strategies, resistant to climate, and support policies.

- Information asymmetry. It's presented when market actors have different information, therefore 
it is considered unreliable or inadequate to support decision making (from basic data to feasibility assessments and relevant policies results).

- Financial constraints.

- Limited access to information and/or knowledge.

- Responsibilities overlapping among institutions leading to inefficient and ineffective adaptation measures implementation.

V. Expected results formulation. Once the first four steps are completed, sufficient information will be available to specify the measure, initiative or adaptation project. It should be considered: a. Expected results $b$. Tangible services/products that will be provide by the initiative c. Activities and inputs needed to obtain services or products and key results. At this stage, the proposed draft measure should also consider funding aspects as well as information and implementation monitoring. The expected results should have rigorous indicators that allow monitoring and success measuring.

VI. Review the first 5 steps. It is appropriate for the designer to review all the stages and to ensure that they meet requirements requested by financing funds. Accessing financial resources for adaptation projects is not an easy task. In the particular case of the United Nations Adaptation Fund (AF) [34], funding request should come from an institution previously accepted as an "Implementing Entity" that is responsible to the Fund, with the possibility to create a "Network" considering government entities, academia and basin organizations. The fundamental requirement is a proposal with a detailed adaptation project description, taking into account social participation (gender equity, women's empowerment and social benefits), alignment with the Fund philosophy and mainly that the proposed project supports but doesn't finance national policies. Other criteria consider the following aspects: relevance, feasibility, institutional arrangements and capacity for project implementation. In general terms, we should be "ready for financing" [35, 36].

\subsection{CRITERIA THAT SHOULD BE EVALUATE TO SELECT AN ADAPTATION MEASURE}

Adaptation measures should have some basic characteristics, which should be evaluated at the time of their selection as part of the design process. According to the International Agency for German Cooperation GIZ [37] criteria to be considered are: feasible, evaluable, equitable, credible, synergistic, aligned with government policies, budgeted, reversible and barriers existence. The National Climate Change Strategy [7] proposes twelve criteria that should be considered when selecting the most appropriate adaptation measures, some of which are explained below:
- Relevance. There should be congruence between adaptation strategy objectives, necessities identified and population and institutions interests (social consensus).

- Impact. It should have positive long-term effects. Unfortunately there will also be negative effects, produced directly or indirectly by this measure.

- Monitoring and evaluation. Strategic impact indicators should be defined focusing on measure compliance and effectiveness. Only through them partial or complete objective fulfillment for which it was designed could be verified; and its application in other places with similar characteristics can be recommended. [38] comment some methodologies for adaptation practices evaluation.

- Feasibility. The measure should consider institutional, financial, political, regulatory, technical and, above all, social capacity that allows its implementation and sustainability.

- Cost effectiveness. Measure cost should be low compared to its effectiveness or benefits to reduce vulnerability. Its calculation represents a challenge.

- Effectiveness. It has to do with the extent to which intervention objectives are achieved or expected to be achieved, taking into account their relative importance.

- Efficiency. It is the extent to which resources (inputs: funds, time, others) have become results. This characteristic should be clearly stated from the adaptation measure design, corresponding to the solution of some of the vulnerabilities detected in the first stage.

- Transversality with policies, programs or projects. The measure should be coherent and able to be combined with climate change policy instruments, such as the National Climate Change Strategy [7], state, municipal and sectoral climate change programs, others.

- Sustainability. Changes achieved through the adaptation project implementation should continue once the intervention is completed. From the stage of selection or design, the mechanism by which the measure can be maintained over time should be considered.

- Active participation of the target population, incorporating their knowledge in all phases of the process, causing the measure appropriation.

\section{CASE STUDY: EFFICIENCY OF ADAPTATION POLICIES IN SMALL MEXICAN AGRICULTURE}

The agricultural sector in Mexico presents a high vulnerability to climate change impacts in the medium term, specifically, small-scale agriculture or farmer family agriculture, which accounts for almost $40 \%$ of agricultural Gross Domestic Product GDP [39]. This activity is carried out mainly in the so- 
called "Rural Economic Units" or REU. At present, family agriculture is strategically positioned to deal with food supply problems at affordable prices for the population [40]. Within this context, it is of particular interest to review the degree of success of adaptation policies in the Mexican small-farming sector.

According to $[41,42]$ in Mexico, agricultural activity consumes $77 \%$ of the total available water, while the remaining $23 \%$ is distributed in other activities such as public sector $(13.9 \%)$ and industry (9\%). Despite these statistics, farming shows exhaustion signs reflected in a stagnation of productivity, competitiveness and profitability, is not inclusive and lacks of natural resources sustainable management. [16, 41] state that there are around 30 million agricultural hectares in the country, of which 6.4 million are irrigated and the rest depends on rainy seasons. Productivity in irrigated areas is, on average, 3.7 times higher than in the rainy season, despite its significantly lower surface area. $79 \%$ of the agricultural area is cultivated during rainy seasons, reason why the production is more exposed to climatic effects (droughts, floods, frosts, others). Despite climatic variations, Mexico ranks among the top ten world powers in food production, being the world's leading avocado producer and concentrated citrus juice.

Although advances in public policies and institutional development in environment, climate change and transversality areas, which provide a basis for uniting efforts between agrarian and climate change policies, there are serious shortcomings in the implementation and execution of programs and governance measures. In the particular topic of adaptation policies and their linkage with family agriculture at the national level, the following problems should be specified, which context has also been studied by the Food and Agriculture Organization of the United Nations FAO and other authors [8, 39].

- Food security is mentioned in the speeches and programs, but no links are detected with adaptation strategies design and family agriculture.

- There are deficiencies in the implementation and execution of government measures and programs; most vulnerable regions have insufficient information on the effectiveness of climate change adaptation policies.

- In general, government plans and programs don't incorporate information on climate or expected climate change into planning. They express policies that would usually be encouraged without the threat of climate change.

- Agricultural production is highly sensitive to climate change. Some examples are: lower crop yields in warmer environments due to heat stress, pest and fire increased, water availability reduction and quality problems. Extreme hydrometeorological phenomena can cause severe crops damage, soil erosion, inability to cultivate due soil water saturation, adverse effects on water quality and water stress.

- Farmworkers have developed adaptive capacities to face climate change. However, this knowledge has not been taken into account by the government. Examples of the competences developed are: Use of varieties/species that show adaptations to climate and requirements of hibernation or increased resistance to heat and drought; Increase of soils organic matter content through manure application, green manures, cover crops for greater moisture retention; Harvesting rainwater, conserving soil moisture through various techniques and efficient use of irrigation water; Water management to prevent flooding, erosion and nutrient leaching when rainfall increases; Use of diversification strategies such as intercropping or agroforestry; Pest and disease prevention through the development and use of resistant varieties and species.

- At local level, a welfare policy has been implemented that does not remedy root causes of the crisis, opportunities loss and life quality of peasant families, who are forced to abandon their lands or allow the young population to migrate to urban areas in search of opportunities.

The little or no efficiency of adaptation policies in small Mexican agriculture can also be verified through the document [40], which states that one of the constraints faced by small-scale agriculture in Mexico has to do with high vulnerability to climate contingencies and natural resources degradation. Other causes refer to the low development level of human capital, lack of capital goods, low level of technology and weak integration of productive chains. In addition, this document mentions that the adverse weather phenomena presented in municipalities where the REUs corresponding to the family agriculture segment are located as follows: in 2006, $38.1 \%$ of municipalities suffered extreme rains and $32.8 \%$ droughts; while in $201133.0 \%$ suffered droughts, $32.1 \%$ extreme rains and $24.0 \%$ hail, frost or snow.

\section{CONCLUSION}

Climate change is a warning signal to which adaptation is the answer to minimize its impacts or exploit opportunities. However, selecting, proposing and designing the most appropriate measures for effective adaptation and achieving the greatest impact is not an easy task. It is possible to find information in the literature on this subject, but it is not enough. For this reason, in this paper relevant topics were approached in such a way that a reader can count on a guide and answer key questions. A case study related to climate change 
and its impact on small-scale agriculture in México is also presented.

Proposals for adaptation projects should be concrete and clearly address the problem, considering a feasibility analysis. Also, basic characteristics, such as: be feasible, evaluable, equitable, credible, synergistic, aligned with government policies, budgeted, reversible. Measures should also respond to specific necessities of each region and take priority attention to the most vulnerable sectors. It is also crucial that any adaptation project identifies barriers, how to overcome them and the associated costs to capitalize those actions.

Adaptation is an interdisciplinary learning process that takes into account knowledge, experiences and the role of individuals, organizations and ecosystems, so that the development of an adaptive capacity allows to reduce vulnerability to climate changes.

Relationship between climate and society is close. Knowledge of current and future risks and potential impacts on societies provides a guide for adaptation. Environmental, economic, cultural and social damage caused by climate change has a direct impact on productive sectors (agriculture, water, health, coastal, energy, food production) and on human settlements in different countries geographical areas. Benefits of implementing adaptation measures to face climate change far outweigh the costs of doing nothing.

Adaptation measures selection requires a detailed evaluation of advantages and disadvantages of each alternative, considering possible interest conflicts between sectors and other policies. Multicriteria assessments that consider environmental, economic, and social factors to weight the value of an adaptation alternative are more efficient than cost-benefit assessments that only take into account alternatives economic benefits.

Climate change threatens production and productivity stability in the agricultural sector. In order to protect it, it is a priority to move towards climate-smart production systems [8] and thus increase productivity, resilience and strengthen food security. Some strategies that should be implemented that are part of this concept are: productive reconversion, conservation agriculture, agroforestry and integrated and diversified food and energy systems.

Government should strive to achieve effective management of plans and programs to face climate change challenges with a solid agrarian policy.

\section{REFERENCES}

[1]. D.H. Meadows, D.L. Meadows, J. Randers, and W.W. Behrens, Los límites del crecimiento: informe al Club de Roma sobre el predicamento de la humanidad (Donella Meadows Ed., Fondo de Cultura Económica, 1972).

[2]. Comisión Nacional para el Conocimiento y Uso de la Biodiversidad CONABIO, https://www.gob.mx/conabio

[3]. P. Guido, Manual para la selección, clasificación y diseño de medidas de adaptación al cambio climático, (Instituto Mexicano de Tecnología del Agua. Proyecto Interno DP1608.1, 2016).

[4]. Banco Mundial, Impactos del incremento del nivel medio del mar en la zona costera del estado de Campeche, México, (Banco Mundial, 2012). http://www.semarnatcam.campeche.gob.mx/fi les/impactos_del_incremento_en_el_ma.pdf

[5]. P. Guido, A. Ramírez, L. Godínez, S. Cruz, B. Juárez. Estudio de la erosión costera en Cancún y la Riviera Maya, México, Avances en Recursos Hidráulicos, (20), 2009, 41-56.

[6]. IPCC, 2014, Climate Change 2014: Synthesis Report. Contribution of Working Groups I, II and III to the Fifth Assessment Report of the Intergovernmental Panel on Climate Change [Core Writing Team, R.K. Pachauri and L.A. Meyer (Eds.)]. IPCC, Geneva, Switzerland, $151 \mathrm{pp}$.

[7]. Estrategia Nacional de Cambio Climático. Visión 10-20-40 (2013), http://www.semarnat.gob.mx/archivosanterior es/informacionambiental/Documents/06_otras /ENCC.pdf

[8]. FAO. Agricultura Climáticamente Inteligente. Políticas, prácticas y financiación para la seguridad alimentaria, adaptación y mitigación, (FAO, 2010) http://www.fao.org/3/a-i1881s.pdf

[9]. I. Burton and Development Programme United Nations, Adaptation policy frameworks for climate change: developing strategies, policies and measures, (B. Lim Ed. Cambridge: Cambridge University Press, 2005).

[10]. Diario Oficial de la Federación, Ley General de Cambio Climático, 6 de junio del 2012, México.

[11]. Programa Especial de Cambio Climático 2014 - $2018 \quad$ PECC. http://www.cenapred.unam.mx/es/documento sWeb/Avisos/cambio_climatico.pdf

[12]. M. Behnassi, The Energy-Water-Food Nexus and Climate Change: Implications for Policy- 
making, Research, and Business. Climate Change, 2017, 3(9), 153-156.

[13]. R.H. Mohtar \& B. Daher, Water-Energy-Food Nexus Framework for facilitating multistakeholder dialogue, Water International, 2016, DOI:10.1080/02508060.2016.1149759

[14]. DARA and the Climate Vulnerable ForumClimate Vulnerability Monitor, The State of the Climate Crisis. Report of the Climate Vulnerability Initiative, (Editor DARA, 2010. ISBN: 978-84-614-5713-7. 290 p).

[15]. V. Magaña, Guía metodológica para la evaluación de la vulnerabilidad ante cambio climático, (INE, 2012).

[16]. Secretaría del Medio Ambiente y Recursos Naturales SEMARNAT. http:// www.semarnat.gob.mx/

[17]. Secretaría de Energía SENER. https://www.gob.mx/sener

[18]. Diario Oficial de la Federación DOF https://www.dof.gob.mx

[19]. UNFCCC.

http://unfccc.int/adaptation/cancun_adaptation _framework/national_adaptation_plans/items/ 6057.php

[20]. H. Füssel, Adaptation planning for climate change: concepts, assessment approaches, and key lessons, Sustain Science (2), 2007, 265275.

[21]. I.R. Noble, S. Huq, Y.A. Anokhin, J. Carmin, D. Goudou, F.P. Lansigan, B. Osman-Elasha, and A. Villamizar, Adaptation needs and options, (In: Climate Change 2014: Impacts, Adaptation, and Vulnerability).

[22]. G. Yohe and R. Tol, Indicators for social and economic coping capacity: Moving toward a working definition of adaptive capacity, Global Environmental Change (12), 25-40.

[23]. UK Climate Impacts Programme, Identifying adaptation options,

http://www.ukcip.org.uk/wpcontent/PDFs/ID_Adapt_options.pdf

[24]. G. Magrin, Adaptación al cambio climático en América Latina y el Caribe, (CEPAL, 2015).

http://repositorio.cepal.org/handle/11362/398 42

[25]. J.B. Smith, Setting priorities for adapting to climate change, Global Environmental Change, 7(3), 1997, 251-264.

[26]. S. Fankhauser, J.B. Smith, R.S. Tol, Weathering climate change: some simple rules to guide adaptation decisions, Ecology Economy 30, 1999, 67-78.

[27]. United Nations Development Programme (UNDP), A toolkit for designing climate change adaptation initiatives, (UNDP, New York, New York, USA, 2010).
[28]. B. Lim, E. Spanger-Siegried, I. Burton, I., E. Malone, Sa. Huq, Marco de Políticas de Adaptación al Cambio Climático, Desarrollando Estrategias, Políticas y Medidas, (PNUD, GEF, 2005).

[29]. K. Ebi, B. Lim B y Y. Aguilar, Marco de Políticas de Adaptación del PNUD, (Eds: B. Lim and E. Spanger-Siegfrie 2005). http://www.undp.org/climatechange/adapt/apf .html.

[30]. United Nation Development Group UNDG, Cómo preparar un MANUD: Parte (II). Guía técnica para los equipos de país de las Naciones Unidas.

[31]. O. Ostergaard and J. Reenberg, Cultural barriers to climate change adaptation: A case study from Northern Burkina Faso, Global Environmental Change, 20, 2010, 142-152. doi:10.1016/j.gloenvcha.2009.10.002.

[32]. S. Moser and J.A. Ekstrom, A framework to diagnose barriers to climate change adaptation (R. Kasperson, Ed., 2010) PNAS, 107(51). doi:10.1073/pnas.1007887107.

[33]. M. Islam, S. Sallu, K. Hubacek and J. Paavola, Limits and barriers to adaptation to climate variability and change in Bangladeshi coastal fishing communities, Marine Policy, 43, 2014, 208-216.

[34]. Adaptation Fund AF (Fondo de Adaptación de las Naciones Unidas), https://www.adaptation-fund.org/

[35]. PNUD, Catalizando el Financiamiento para Enfrentar el Cambio Climático, (PNUD, $\left.2011^{\mathrm{a}}\right)$.

[36]. V. Vandeweerd, S. Billett and Y. Glemarec, Preparación para financiamiento climático: un marco para entender qué significa estar listo para utilizar el financiamiento climático, 2012.

http://bibliotecavirtual.minam.gob.pe/biam/bit stream/handle/minam/1310/BIV01082.pdf?se quence $=8 \&$ is Allowed $=\mathrm{y}$

[37]. GIZ, Metodología para la identificación y priorización de medidas de adaptación, (Elaborado por el Componente de Adaptación de la Alianza Mexicana-Alemana de Cambio Climático de la GIZ. Documentos contenidos en CD interactivo, 2013a).

[38]. P. Aldunce, C. Neri y C. Szlafsztein, Hacia la evaluación de prácticas de adaptación ante La variabilidad y el cambio climático, (Belém: NUMA/UFPA, 2008).

[39]. R. Landa, Políticas nacionales de adaptación al cambio climático y su vínculo con la agricultura familiar, (OXFAM, CRECE, 2014) http://oxfammexico.org/crece/wp- 
Pedro Antonio Guido-Aldana. Int. Journal of Engineering Research and Application www.ijera.com ISSN : 2248-9622, Vol. 7, Issue 4, ( Part -2) April 2017, pp.20-29

content/uploads/2014/12/POLITICAS-CC-

Final.pdf

[40]. Secretaría de Agricultura, Ganadería, Desarrollo Rural, Pesca y Alimentación, SAGARPA. Agricultura familiar con potencial productivo en México, (SAGARPAFAO,2012).

http://www.sagarpa.gob.mx/programas2/evalu acionesExternas/Lists/Otros\%20Estudios/Atta chments/42/Agricultura\%20Familiar_Final

[41]. CONAGUA, Estadísticas del agua en México. (CONAGUA 2015).

[42]. Secretaría de Medio Ambiente y Recursos Naturales. Comisión Nacional del Agua Subdirección General de Planeación, (Numeragua México, 2015).

\section{AUTHORS BIOGRAPHY}

Pedro Antonio Guido-Aldana. Researcher.

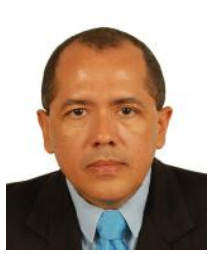

Mexican Institute of Water Technology - IMTA, Mexico. Dr. and Master in Hydraulics by the National Autonomous University of Mexico-UNAM, Civil Eng. Research interest: water planning, climate change, potamology,

Particle Image Velocimetry.

Adriana María Ramírez-Camperos. Consultant on Water and Energy, Mexico. Dr. in

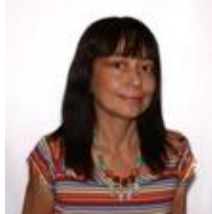
Eng. (Energy Economy) and Master in Water Resources by UNAM. Professor in the Institute of renewable Energies-UNAM Research interest: energy policy, energy prospects, energy sector laws and reforms, climate change. 